\title{
Viability of the Microencapsulation of Lactobacillus casei TISTR 390 Containing Inulin in Simulated Gastrointestinal Conditions and Storage
}

\author{
Poonyanuch Nilsang \\ Faculty of Science and Technology, Valaya Alongkorn Rajabhat University, Pathumtani 13180, Thailand
}

(Corresponding author's e-mail: poonyanuch@vru.ac.th)

Received: 2 May 2020, Revised: 1 May 2021, Accepted: 2 May 2021

\begin{abstract}
This research aimed to determine the process condition for microencapsulation of Lactobacillus casei TISTR 390 by spray drying with maltodextrin and inulin as the coating agent. The physical properties and survivability of the microencapsulated cell were evaluated under simulated gastrointestinal conditions and during storage. Firstly, 3 inlet temperatures $\left(150,160\right.$ and $\left.170{ }^{\circ} \mathrm{C}\right)$ and 3 maltodextrin levels $(5,10$ and $15 \%(\mathrm{w} / \mathrm{v}))$ were examined. The result reveals that an optimum condition was at $160{ }^{\circ} \mathrm{C}$ inlet temperature with $15 \%$ maltodextrin. Subsequently, inulin was added in 3 combinations; T1 (15\% maltodextrin and $5 \%$ inulin (w/v)), T2 (10\% maltodextrin and $10 \%$ inulin (w/v)) and T3 (5\% maltodextrin and $15 \%$ inulin (w/v)) in an effort to generate synbiotic powder products. The best result was observed with a combination of $10 \%$ maltodextrin and $10 \%$ inulin. The obtained powder had a moisture content of $1.5 \pm 0.01 \%$, a water activity of $0.28 \pm 0.02$, a total density of $0.71 \pm 0.04 \mathrm{~g} / \mathrm{mL}$, a solubility of $84.71 \pm 0.01 \%$, and a lactobacilli survival rate after spray drying of $90.76 \%$. The microencapsulated lactobacilli containing inulin powders were able to survive in acidic ( $\mathrm{pH} 2$ ) and bile salt solution $(2 \% \mathrm{w} / \mathrm{v})$ after $120 \mathrm{~min}$ of incubation time with more than $60 \%$ of the cell surviving. Furthermore, the microencapsulated powders were kept in aluminum-laminated bags at room temperature for 6 weeks and it was found that the cell viability remained at $6 \log \mathrm{CFU} / \mathrm{g}$. Therefore, a combination of an equal weight of maltodextrin and inulin was a promising protection agent for L. casei TISTR 390 in the simulated gastrointestinal conditions and during storage at ambient temperature.
\end{abstract}

Keywords: Viability, Lactobacillus casei, Microencapsulation, Gastrointestinal

\section{Introduction}

Probiotic bacteria have been defined as live microorganisms which when administered in adequate amounts confer health benefits to humans and animals when consumed in sufficient numbers typically $10^{6}-10^{7} \mathrm{CFU} / \mathrm{g}[1,2]$. They prevent gastrointestinal infections, diarrhea, inflammatory bowel disease, decrease serum lipids and improve the immune system; owing to anti-carcinogenic, antibacterial, and anti-mutagenic effects [3]. Currently, the food industry has been interested in developing new functional food products concerned about nutrition and foods with probiotics that stand out in the market. For probiotics to be therapeutically effective, it has been suggested that products should contain at least 6 $\log \mathrm{CFU} / \mathrm{g}$ of bacteria up to the end of its shelf life, and it is recommended that probiotic food should contain a minimum of $10^{8} \mathrm{CFU}$ per gram or milliliter at the time of consumption [4]. However, most probiotics are sensitive and easily lose their viability when exposed in stressful conditions. To improve the resistance of probiotics against harsh environments, microencapsulation is one of the most efficient methods that can be used to enhance the viability during processing and storage $[5,6]$.

Microencapsulation is the process of encapsulating substances with a state of solids, liquids, and gases with polymers or coating material to form small capsules. Among the several microencapsulation techniques, spray drying is a commonly used method due to its low energy consumption, less cost, higher production efficiency, storage and appears to be a good alternative for large-scale production of probiotic powders [4,7]. Although, during the spray drying process, the membrane of probiotics cells may get damaged from dehydration and thermal stress that may cause a reduction in bacterial cell survival $[6,8]$.

In recent years, many studies have been conducted on microencapsulation for the preservation of probiotic microorganisms during processing, storage, subsequent consumption, and gastrointestinal transit [5,7,9-12]. Different food material has been used as a carrier wall material for encapsulated probiotics by 
spray drying such as reconstituted skim milk (RSM) maltodextrin, gum acacia, gum arabic, whey proteins, and modified starch [3-6,11-14]. Each of these carriers showed advantages and disadvantages in terms of cost, process efficiency, and effect on the characteristics of the final product. For example, gum acacia showed better performance than maltodextrin due to the higher glass transition temperature, but its high cost compared to maltodextrin is its disadvantage [15]. However, the combination of maltodextrin and gum acacia along with milk protein could prolong the shelf life of the spray-dried powder when stored at $4{ }^{\circ} \mathrm{C}$ [12]. Another approach to increase the viability of probiotic bacteria is the use of prebiotics, which are non-digestible food ingredients that beneficially affect the host by selectively stimulating the growth and/or activity of bacteria in the colon. In 2016, The International Scientific Association of Probiotics and Prebiotics (ISAPP) proposed a new definition of a prebiotic as "a substrate that is selectively utilized by host microorganisms conferring a health benefit" [17]. Prebiotic and probiotic combination, known as synbiotic has been shown to improve probiotic proliferation in the intestine and helps in modifying the gut community [12]. Inulin is a prebiotic which is extracted from chicory roots, onions, artichokes, etc. Inulin aids digestion by increasing the number of good bacteria in the gut, particularly Bifidobacteria and Lactobacilli. Slizewska et al. [17] reported that a synbioic combination of probiotics Latobacillus spp. stains with $2 \%(\mathrm{w} / \mathrm{v})$ inulin could help prevent gastrointestinal infections and maintain proper $\mathrm{pH}$ levels in the gastrointestinal tract, leading to balanced microbiota. Moludi et al. [18] showed the combination of probiotic strain, Lactobacillus ramnosus $\mathrm{G}$ with a prebiotic, inulin that could improve psychological outcomes and inflammatory biomarker in patients with coronary artery diseases.

Paim et al. [14] also found that Bifidobacterium spp. lactis microencapsulated by using maltodextrin and inulin (1:1) as a carrier in jussara juice displayed viability cell count after spray-dried above 6 log CFU/g. Moreover, the microencapsulation bifidobacteria with oligofructose-enrich inulin showed better protection during storage [5].

Therefore, the objective of this study was to evaluate the effect of temperature and maltodextrin level on the viability of $L$. casei TISTR 390 microencapsulated by spray drying in a simulated gastric environment. Hence to further exploit as synbiotic, the L. casei TISTR 390 were microencapsulated with prebiotic, inulin, and then its ability to tolerate simulated gastric juice was evaluated. In addition, the storage viability of microencapsulated cells was also determined.

\section{Materials and methods}

\section{Bacterial preparation}

A probiotic lactic acid bacterium, L. casei TISTR 390, was obtained from the Microbiological Resources Center at the Thailand Institute of Scientific and Technological Research in Pathumthani, Thailand. The culture was grown at $37^{\circ} \mathrm{C}$ for $48 \mathrm{~h}$ in a de Man Rogosa and Sharpe (MRS) broth and used as inoculum. After the incubation, probiotic cells were harvested and washed twice with $0.85 \%(\mathrm{w} / \mathrm{v})$ sterile saline water by centrifugation at $4000 \mathrm{rpm}$ for $15 \mathrm{~min}$ at $4{ }^{\circ} \mathrm{C}$ to obtain a bacterial concentration of $10 \log \mathrm{CFU} / \mathrm{g}$.

\section{Microencapsulation procedure}

Microencapsulated L. casei TISTR 390

Skim milk powder and maltodextrin (DE10) were used as the wall materials according to a modified method of Dimitrellou et al. [19]. Briefly, spray-dried feed media is consisted of RSM (200 g/L) by dissolving with the carrier in distilled water and autoclaving at $105^{\circ} \mathrm{C}$ for $5 \mathrm{~min}$. Maltodextrins $(5,10$ and $15 \%(\mathrm{w} / \mathrm{v})$ ) were used as carrier. A mini spray dryer (B191, Buchi, Switzerland) was used to produce samples at an inlet temperature of 150,160 and $170^{\circ} \mathrm{C}$, while the outlet temperature was maintained at 85 - $90^{\circ}$ C. L. casei TISTR 390 was added into the feed solution and fed into the spray chamber through a peristaltic pump with a flow rate of $8 \mathrm{~mL} / \mathrm{min}$. Pressure ranged from $0.7-1.0 \mathrm{~kg} / \mathrm{cm}^{2}$ according to Nilsang [20]. The microencapsulated samples were collected from the base of the cyclone, placed in sterile glass bottles, and stored at $4{ }^{\circ} \mathrm{C}$.

\section{Microencapsulated L. casei TISTR 390 containing inulin}

The experiment was conducted by adding inulin into the feeding media (RSM $200 \mathrm{~g} / \mathrm{L})$ as the following combination of encapsulation agents: T1 (15\% maltodextrin and $5 \%$ inulin (w/v)), T2 (10\% maltodextrin and $10 \%$ inulin $(\mathrm{w} / \mathrm{v}))$ and T3 (5\% maltodextrin and $15 \%$ inulin $(\mathrm{w} / \mathrm{v}))$. The spray drying process was performed precisely as described above at a constant air inlet temperature of $160{ }^{\circ} \mathrm{C}$. The microencapsulated powders obtained then were evaluated for morphology, physical properties, survivability and storage stability. 


\section{Physical Properties of microencapsulated L. casei TISTR 390}

The spray-dried microencapsulated powders were analyzed for moisture content, water activity, bulk density and solubility according to Nilsang [20] as follows. All analytical measurements were carried out in triplicate.

\section{Moisture content}

The moisture content was determined based on the AOAC method [21]. Samples of microencapsulated powders $(2 \mathrm{~g})$ were weighed and dried in an oven at $105^{\circ} \mathrm{C}$ until a constant weight was obtained.

\section{Water activity $\left(a_{w}\right)$}

The water activity meter (AquaLab TE3, Decagon Device, Inc., USA) was used to measure $\mathrm{a}_{\mathrm{w}}$ of the spray-dried powders.

\section{Bulk density}

Microencapsulated powders $(2 \mathrm{~g})$ were gently added into an empty $10 \mathrm{~mL}$ graduated cylinder which was held on a vortex vibrator for $1 \mathrm{~min}$. The ratio of the mass of the powder and the volume occupied in the cylinder determined the density value.

\section{Solubility}

The solubility of the microencapsulated powders was determined using the method described by Kunapornsujarit et al. [22]. The spray-dried powders $(1 \mathrm{~g})$ and distilled water $(10 \mathrm{~mL})$ were vigorously mixed at $30^{\circ} \mathrm{C}$ for $30 \mathrm{~min}$ and then centrifuged at $3000 \mathrm{rpm}$ for $10 \mathrm{~min}$. The supernatant was carefully collected in an aluminum can and oven-dried at a temperature of $105 \pm 2{ }^{\circ} \mathrm{C}$ for $24 \mathrm{~h}$. The solubility (\%) was calculated as the percentage of dried supernatant concerning the amount of the original $1 \mathrm{~g}$ of spraydried powder.

\section{Scanning electron microscopy (SEM)}

The structure of the microencapsulated powder particles was evaluated using a scanning electron microscope JSM-5410 LV (JEOL Ltd., Japan) at $20 \mathrm{kV}$. Powders were coated with a thin layer of palladium in JEC-1200 Fine Coater. (JEOL Ltd., Japan). The coated samples were observed under a microscope and surface structures of particles were evaluated with 1500 magnification.

\section{Survival of microencapsulated powder}

Viable cell count and survival rate of microencapsulated $L$. casei TISTR 390 were established according to Zhu et al. [11]. One g of microencapsulated powders was serially diluted in $9 \mathrm{~mL}$ sterile 0.85 $\% \mathrm{NaCl}$ solution and plated on MRS agar. The survival rate was calculated as follows:

Survival rate $(\%)=\left(\mathrm{N} / \mathrm{N}_{0}\right) \times 100$

where $\mathrm{N}$ represents the number of viable cells after the spray drying process and $\mathrm{N}_{0}$ is the number of viable cells $(\mathrm{CFU} / \mathrm{g})$ of $1 \mathrm{~g}$ of dry matter in the bacterial suspension before drying.

\section{Survival in simulated gastrointestinal conditions}

Survival of microencapsulated $L$. casei TISTR 390 to the simulated gastric juice and bile salt condition was carried out according to the modified method of Kingwatee et al. [23]. Briefly, $0.5 \mathrm{~g}$ of microencapsulated powder was inoculated into $9.5 \mathrm{~mL}$ sterile peptone water, which adjusted to $\mathrm{pH} 2.0$ using $37 \%$ hydrochloric acid. The suspension was subsequently incubated at $37^{\circ} \mathrm{C}$. To determine cell survival, $1 \mathrm{~mL}$ solution was collected in 30,60,90 and $120 \mathrm{~min}$, then poured on MRS agar plates and incubated at $37^{\circ} \mathrm{C}$ for $48 \mathrm{~h}$. After the incubation period, their colonies were counted as cell viability in simulated gastric juice (CFU/g). To determine cell viability in bile salt, $0.5 \mathrm{~g}$ of microencapsulated powder was transferred in test tubes containing $9.5 \mathrm{~mL}$ peptone water with $0.2 \%(\mathrm{w} / \mathrm{v})$ bile salt. A further performance was conducted following the same protocol as simulated gastric juice. The survival rate to simulated gastrointestinal conditions $(120 \mathrm{~min})$ compares to the initial count before exposure to simulated gastric juice and bile salt solution were calculated. 


\section{Storage stability of Microencapsulated $L$. casei TISTR 390 containing inulin}

Microencapsulated $L$. casei TISTR 390 containing inulin powders were seal-packed in the aluminum-laminated bags (PET/AL/PE, $200 \mu \mathrm{m}$ thickness) and store in a desiccator at room temperature $\left(32-35{ }^{\circ} \mathrm{C}\right)$ for 6 weeks. The moisture content, $\mathrm{a}_{\mathrm{w}}$ and the viable cell count of the powders were investigated comparing with the microencapsulated L. casei TISTR 390 without inulin powder. The survival rate to storage for 6 weeks compared to the initial count after spray drying was calculated.

\section{Statistical analysis}

One-way analysis of variance (ANOVA) using SPSS 19.0 statistical software (SPSS Inc., Chicago, IL) was used for the determination of the differences between different treatments. The results were expressed as the mean \pm standard deviation (SD) and considered significantly different when $\mathrm{p} \leq 0.05$.

\section{Results and discussion}

Physical characteristic and survival of microencapsulated $L$. casei TISTR 390 powder

To study the effect of temperature and maltodextrin content on the physical characteristic of the microencapsulated L. casei TISTR 390, the experiments were conducted at 3 different air inlet temperatures $\left(150,160\right.$ and $\left.170{ }^{\circ} \mathrm{C}\right)$ and maltodextrin content $(5,10$ and $15 \% \mathrm{w} / \mathrm{v})$. The moisture content, water activity, bulk density, solubility, and survival of microencapsulated cells were given in Table 1. It was determined that the inlet air temperature had no significant $(\mathrm{p}>0.05)$ effect on water activity, bulk density, and solubility. The moisture content and water activity of the microcapsules were ranged in 2.3 $3.9 \%$ and $0.21-0.37$, respectively. However, the moisture content of the microcapsule obtained from the $150{ }^{\circ} \mathrm{C}$ air inlet was significantly higher than obtained from 160 and $170{ }^{\circ} \mathrm{C}$ inlet air. Water activity is one of the most important quality aspects for product storage and stability. It is known that water activity between 0.28 - 0.40 was recommended for spray-dried microcapsule to ensure microbiological stability and oxidative stable [24]. Poddar et al. [25] were reported that spray-dried L. paracasei CRL 431 is found to survive better when water activity was lower than 0.33 . Similar results were found from this present study, the survivability of the microencapsulated powder obtained from different inlet temperatures and maltodextrin contents were $90 \%$ surviving. Similar observed by Gul and Dervisoglu [6] who reported that $\mathrm{a}_{\mathrm{w}}$ value decrease with an increase in air inlet temperature and this was good for the commercial production of spray-dried powders with good handling such as low tackiness and agglomeration, high fluidity as well as maximum probiotic viability. In contrast, at a lower air inlet temperature $\left(150{ }^{\circ} \mathrm{C}\right)$ the higher moisture content was found than at high air inlet temperature $\left(160\right.$ and $\left.170{ }^{\circ} \mathrm{C}\right)$. This behavior is similar to what was observed by Medeiros et al. [26], they also reported that at a lower moisture content, it could minimize caking which prevents powder flow and dispersion.

Table 1 Physical properties of microencapsulated L. casei TISTR 390 at different spray drying conditions.

\begin{tabular}{|c|c|c|c|c|c|c|}
\hline $\begin{array}{c}\text { Inlet } \\
\text { Temp } \\
\left({ }^{\circ} \mathrm{C}\right)\end{array}$ & $\begin{array}{c}\text { Maltodextrin } \\
(\%)\end{array}$ & $\begin{array}{c}\text { Moisture } \\
(\%)\end{array}$ & $\mathbf{a}_{\mathbf{w}}$ & $\begin{array}{l}\text { Bulk density } \\
\quad(\mathrm{g} / \mathrm{mL})\end{array}$ & $\begin{array}{c}\text { Solubility } \\
(\%)\end{array}$ & $\begin{array}{c}\text { Survival } \\
(\%)\end{array}$ \\
\hline \multirow[t]{3}{*}{150} & 5 & $3.6 \pm 0.00^{\mathrm{a}}$ & $0.38 \pm 0.01^{\mathrm{a}}$ & $0.72 \pm 0.02^{\mathrm{a}}$ & $72.46 \pm 0.02^{\mathrm{a}}$ & $90.86 \pm 1.0^{\mathrm{a}}$ \\
\hline & 10 & $3.9 \pm 0.02^{\mathrm{a}}$ & $0.28 \pm 0.03^{b}$ & $0.74 \pm 0.01^{\mathrm{a}}$ & $71.76 \pm 0.01^{\mathrm{a}}$ & $90.46 \pm 1.8^{\mathrm{a}}$ \\
\hline & 15 & $3.8 \pm 0.01^{\mathrm{a}}$ & $0.28 \pm 0.02^{\mathrm{b}}$ & $0.75 \pm 0.03^{\mathrm{a}}$ & $72.64 \pm 0.01^{\mathrm{a}}$ & $90.07 \pm 0.2^{\mathrm{a}}$ \\
\hline \multirow[t]{3}{*}{160} & 5 & $2.8 \pm 0.02^{b}$ & $0.30 \pm 0.00^{b}$ & $0.70 \pm 0.01^{\mathrm{a}}$ & $69.17 \pm 0.56^{\mathrm{a}}$ & $90.50 \pm 0.4^{\mathrm{a}}$ \\
\hline & 10 & $2.4 \pm 0.00^{\mathrm{b}}$ & $0.27 \pm 0.02^{b}$ & $0.72 \pm 0.02^{\mathrm{a}}$ & $69.91 \pm 0.12^{\mathrm{a}}$ & $90.18 \pm 1.2^{\mathrm{a}}$ \\
\hline & 15 & $2.3 \pm 0.02^{\mathrm{b}}$ & $0.22 \pm 0.01^{\mathrm{b}}$ & $0.74 \pm 0.01^{\mathrm{a}}$ & $70.05 \pm 0.02^{\mathrm{a}}$ & $90.60 \pm 1.1^{\mathrm{a}}$ \\
\hline \multirow[t]{3}{*}{170} & 5 & $2.3 \pm 0.00^{\mathrm{b}}$ & $0.23 \pm 0.01^{\mathrm{b}}$ & $0.66 \pm 0.01^{\mathrm{b}}$ & $69.50 \pm 0.08^{\mathrm{a}}$ & $90.07 \pm 0.3^{\mathrm{a}}$ \\
\hline & 10 & $2.5 \pm 0.00^{\mathrm{b}}$ & $0.26 \pm 0.02^{b}$ & $0.67 \pm 0.01^{b}$ & $70.03 \pm 0.05^{\mathrm{a}}$ & $90.10 \pm 1.5^{\mathrm{a}}$ \\
\hline & 15 & $2.4 \pm 0.01^{\mathrm{b}}$ & $0.21 \pm 0.02^{b}$ & $0.69 \pm 0.02^{b}$ & $68.80 \pm 0.12^{\mathrm{a}}$ & $90.66 \pm 0.4^{\mathrm{a}}$ \\
\hline
\end{tabular}

Note: Data is presented as mean \pm standard deviation $(\mathrm{n}=3)$

Different superscript in each column represents a significant difference between mean values at $95 \%(\mathrm{p} \leq 0.05)$. 
Koc and Dirim [27] explained that the residual moisture content of the powders has an important effect on the powder properties such as bulk density, solubility, wettability and flow behavior, etc. Solubility is an important parameter to evaluate the behavior of the powders in the aqueous phase, since food powder has high solubility to be useful and functional. The microencapsulated powder obtained in these experiments had high solubility between $69-72 \%$ similar result of spray-dried L. plantarum in lichi juice powder with $15 \%(\mathrm{w} / \mathrm{v})$ maltodextrin $(<20 \mathrm{DE})$ reported by Kalita et al. [28]. Bulk density is a property that influences the packing and shipping of powder products. Lourenco et al. [29] explained that a high bulk density value might result in higher packing due to the lower volume occupied per mass unit, by contrast, at the lower bulk density value may increase the possibility of product oxidation and reduced storage stability. The bulk density values of this work ranged from $0.66-0.75 \mathrm{~g} / \mathrm{mL}$ and the inlet air temperature of $170{ }^{\circ} \mathrm{C}$ showed a significantly low bulk density value than others $(\mathrm{p} \leq 0.05)$. Laokuldilok and Kanha [30] observed that the higher inlet air temperatures produced larger particle sizes when compared to the lower inlet air temperature. The larger particles contained more entrapped air, which resulted in lowering the bulk density. Dried foods with low bulk density often show poor storage. In addition, increasing maltodextrin concentrations leads to an increase in the bulk density of the powder. Similar results were claimed by A-sun et al. [31]. In addition, the results also showed that the increase of the maltodextrin level did not significantly affect the moisture content, $a_{w}$, bulk density, and solubility of the microencapsulated powder. Similar results were claimed by Mishra et al. [32] for amla (Emblica officinalis) juice powder.

SEM was used to observe the morphology changes at different drying conditions. The particles presented spherical shapes and varying sizes, which are characteristic of particles obtained by spray drying. The morphology of the microcapsules taken by SEM is shown in Figure 1. The particles were spherical with a small size and wrinkled surface. In addition, at high inlet temperature were found more wrinkles and shrinkage surfaces than lower inlet temperatures. Navarro-Flores et al. [33] suggested that the inlet air temperature could influence the microstructure of the microcapsules. A temperature $>160{ }^{\circ} \mathrm{C}$ causes a degradation of the spherical structure of the particles. Ghandi et al. [34] explained that the surface of powders obtained at higher inlet temperature is quite rough and uneven with very clearly observed surface folds, troughs, and crests. This can be attributed to the strong moisture gradients the droplets encountered while drying at higher inlet temperatures that resulted in uneven shrinkage. The smoothness of the microcapsule might affect its properties such as solubility and water activity and influencing the number of survival cells [5].

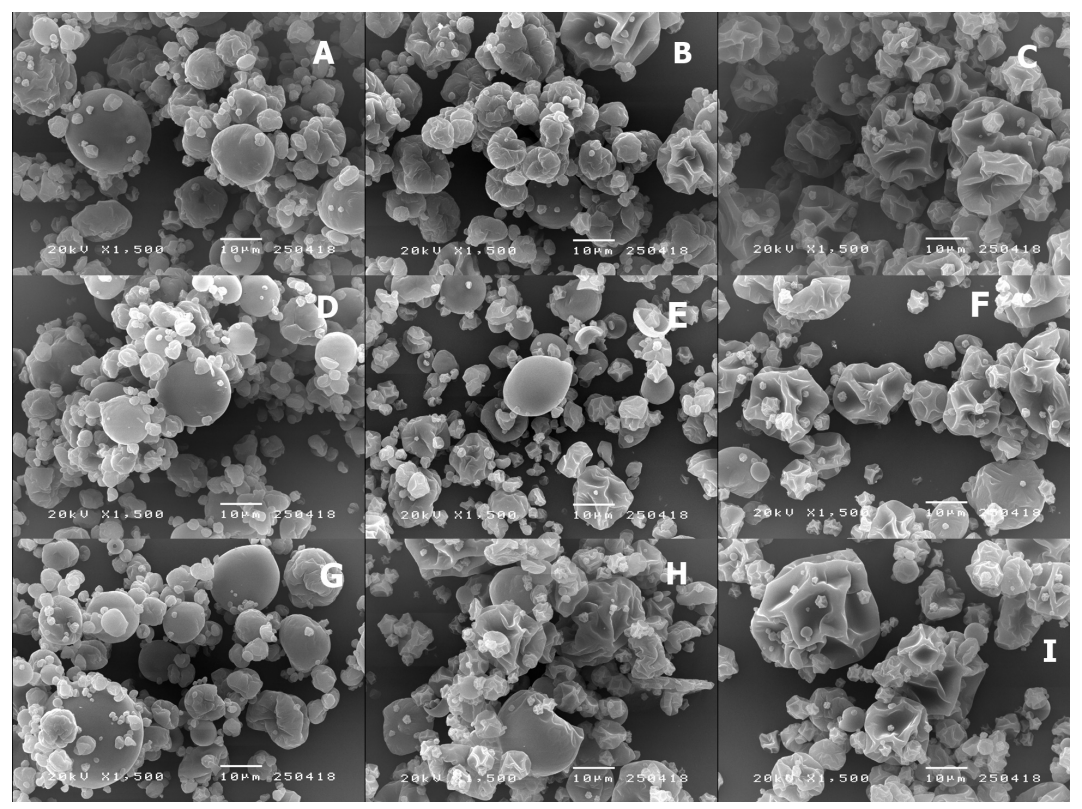

Figure 1 Scanning electron micrographs (1500× magnification) of microencapsulated L. casei TISTR 390 at different spray drying conditions; $\mathrm{A}=150{ }^{\circ} \mathrm{C}+5 \%$ maltodextrin $(\mathrm{MD}), \mathrm{B}=150{ }^{\circ} \mathrm{C}+10 \% \mathrm{MD}$, $\mathrm{C}=150{ }^{\circ} \mathrm{C}+15 \% \mathrm{MD}, \mathrm{D}=160{ }^{\circ} \mathrm{C}+5 \% \mathrm{MD}, \mathrm{E}=160{ }^{\circ} \mathrm{C}+10 \% \mathrm{MD}, \mathrm{F}=160{ }^{\circ} \mathrm{C}+15 \% \mathrm{MD}, \mathrm{G}=$ $170{ }^{\circ} \mathrm{C}+5 \% \mathrm{MD}, \mathrm{H}=170{ }^{\circ} \mathrm{C}+10 \% \mathrm{MD}, \mathrm{I}=170{ }^{\circ} \mathrm{C}+15 \% \mathrm{MD}$. 


\section{The survival rate of microencapsulated $L$. casei TISTR 390 powder in simulated gastrointestinal conditions}

The success of probiotics as a functional food is mainly determined by their ability to survive in digestive stresses during their passage through the gastrointestinal tract. Probiotic bacteria are taken with foods, they are moved from mouth to the stomach and go to the lower intestinal tract. The time between entering and exiting the stomach is about $90 \mathrm{~min}$ [6]. The important property of potential probiotic bacteria is their ability to survive in gastric juice and bile solution in the stomach and small intestine, and to take up residence and multiply in the large intestine. The viability of microencapsulated $L$. casei TISTR 390 in simulated gastric juice and bile salt solution was evaluated and the results are summarized in Tables 2 and 3. The results of cell survivability in gastric juice ( $\mathrm{pH} 2$ ) revealed that the microencapsulated cell could survive in acidic conditions for $120 \mathrm{~min}$ by decreasing from initial stage 3 $4 \mathrm{log}$ cycle or at $50 \%$ survival. The microencapsulated powder was also found more than $6 \log \mathrm{CFU} / \mathrm{g}$ when incubated in a bile solution for $120 \mathrm{~min}$ obtained from all air inlet temperatures. However, at an inlet temperature of $170{ }^{\circ} \mathrm{C}$, the reduction in cell counting was significant after $90 \mathrm{~min}(\mathrm{p}<0.05)$. It was found that at air inlet temperature of $150{ }^{\circ} \mathrm{C}$ the survival rate of cells in acidic conditions was longer period than other temperatures. The maltodextrin content showed no significant effect on the survival rate $(p>0.05)$. The microencapsulated cells had featured a higher survival index in bile salt conditions than that in gastric juice similar to the results reported by Kingwatee et al. [23]. Furthermore, Dimitrellou et al. [19] also demonstrated that the survival of L. casei ATCC 393 cells under the simulated gastric juice ( $\mathrm{pH}$ 2 and 3$)$ and bile salt condition was significantly $(\mathrm{p}<0.05)$ improved by microencapsulation compared to free cells. Hence, the result of the present study showed that the microencapsulated cell at all conditions had the potential to enhance survivability in stimulating gastric juice.

Table 2 Survival of microencapsulated L. casei TISTR 390 in simulated gastric juice.

\begin{tabular}{|c|c|c|c|c|c|c|c|}
\hline \multirow{2}{*}{$\begin{array}{c}\text { Inlet } \\
\text { Temp } \\
\left({ }^{\circ} \mathrm{C}\right)\end{array}$} & \multirow{2}{*}{$\begin{array}{c}\text { Maltodextrin } \\
(\%)\end{array}$} & \multicolumn{5}{|c|}{ Viability in simulated gastric juice (Log CFU/g) } & \multirow{2}{*}{$\begin{array}{c}\text { Survival } \\
(\%)\end{array}$} \\
\hline & & $0 \mathrm{~min}$ & $30 \mathrm{~min}$ & $60 \mathrm{~min}$ & $90 \mathrm{~min}$ & $120 \mathrm{~min}$ & \\
\hline \multirow[t]{3}{*}{150} & 5 & $10.35 \pm 0.2^{\mathrm{a}}$ & $9.27 \pm 0.1^{\mathrm{a}}$ & $8.23 \pm 0.0^{\mathrm{a}}$ & $7.15 \pm 0.0^{\mathrm{a}}$ & $6.99 \pm 0.1^{\mathrm{a}}$ & $67.54 \pm 0.5^{\mathrm{a}}$ \\
\hline & 10 & $10.27 \pm 0.1^{\mathrm{a}}$ & $9.20 \pm 0.2^{\mathrm{a}}$ & $8.16 \pm 0.2^{\mathrm{a}}$ & $7.09 \pm 0.1^{\mathrm{a}}$ & $6.92 \pm 0.0^{\mathrm{a}}$ & $67.38 \pm 0.5^{\mathrm{a}}$ \\
\hline & 15 & $10.25 \pm 0.2^{\mathrm{a}}$ & $9.21 \pm 0.1^{\mathrm{a}}$ & $8.17 \pm 0.1^{\mathrm{a}}$ & $7.06 \pm 0.2^{\mathrm{a}}$ & $6.89 \pm 0.1^{\mathrm{a}}$ & $67.22 \pm 0.4^{\mathrm{a}}$ \\
\hline \multirow[t]{3}{*}{160} & 5 & $10.29 \pm 0.1^{\mathrm{a}}$ & $9.22 \pm 0.1^{\mathrm{a}}$ & $8.13 \pm 0.0^{\mathrm{a}}$ & $7.19 \pm 0.1^{\mathrm{a}}$ & $5.69 \pm 0.1^{\mathrm{b}}$ & $55.30 \pm 0.8^{b}$ \\
\hline & 10 & $10.27 \pm 0.4^{\mathrm{a}}$ & $9.20 \pm 0.1^{\mathrm{a}}$ & $8.15 \pm 0.1^{\mathrm{a}}$ & $7.96 \pm 0.2^{b}$ & $5.72 \pm 0.2^{b}$ & $55.70 \pm 0.9^{b}$ \\
\hline & 15 & $10.31 \pm 0.4^{\mathrm{a}}$ & $9.27 \pm 0.1^{\mathrm{a}}$ & $8.17 \pm 0.0^{\mathrm{a}}$ & $7.78 \pm 0.1^{\mathrm{b}}$ & $5.79 \pm 0.1^{b}$ & $56.16 \pm 1.3^{b}$ \\
\hline \multirow[t]{3}{*}{170} & 5 & $10.24 \pm 0.1^{\mathrm{a}}$ & $9.18 \pm 0.2^{\mathrm{a}}$ & $8.08 \pm 0.1^{\mathrm{b}}$ & $7.79 \pm 0.1^{b}$ & $5.49 \pm 0.1^{\mathrm{b}}$ & $53.61 \pm 1.8^{b}$ \\
\hline & 10 & $10.22 \pm 0.4^{\mathrm{a}}$ & $9.04 \pm 0.1^{\mathrm{a}}$ & $7.98 \pm 0.0^{\mathrm{b}}$ & $7.86 \pm 0.0^{b}$ & $5.55 \pm 0.0^{\mathrm{b}}$ & $54.30 \pm 0.9^{b}$ \\
\hline & 15 & $10.29 \pm 0.1^{\mathrm{a}}$ & $9.24 \pm 0.2^{\mathrm{a}}$ & $8.17 \pm 0.1^{\mathrm{a}}$ & $7.83 \pm 0.1^{b}$ & $5.57 \pm 0.1^{\mathrm{b}}$ & $54.13 \pm 0.8^{b}$ \\
\hline
\end{tabular}

Note: Data is presented as mean \pm standard deviation $(\mathrm{n}=3)$

Different superscript in each column represents a significant difference between mean values at $95 \%(\mathrm{p} \leq 0.05)$.

Overall, the survivability of microencapsulated cells in simulated gastrointestinal conditions of 150 ${ }^{\circ} \mathrm{C}$ and $160{ }^{\circ} \mathrm{C}$ inlet temperature were not significantly different $(\mathrm{p}>0.05)$, but $150{ }^{\circ} \mathrm{C}$ showed a higher survival rate in a longer period of incubation in acidic condition than $160{ }^{\circ} \mathrm{C}$. However, at low inlet temperature, the higher moisture content was performed which might lead to storage problems and loss of stability during storage [35]. In addition, an increase in the maltodextrin concentration from $10-15 \%$ provided no relevant probiotic protection during drying and storage. Maintaining low water activity levels could increase probiotic viability and enhancing microbial physiology and function.

In this study, $160{ }^{\circ} \mathrm{C}$ and $15 \%$ maltodextrin were chosen as the optimal condition for spray drying L. casei TISTR 390 because of the low moisture content, low water activity, high survival rate throughout the gastrointestinal fluids, and able to stabilize during storage. 
Table 3 Viability of microencapsulated L. casei TISTR 390 in simulated bile salt.

\begin{tabular}{|c|c|c|c|c|c|c|c|}
\hline \multirow{2}{*}{$\begin{array}{l}\text { Inlet } \\
\text { Temp } \\
\left({ }^{\circ} \mathrm{C}\right)\end{array}$} & \multicolumn{7}{|c|}{ Viability in simulated bile salt (Log CFU/g) } \\
\hline & & $0 \mathrm{~min}$ & $30 \mathrm{~min}$ & $60 \mathrm{~min}$ & $90 \mathrm{~min}$ & $120 \mathrm{~min}$ & \\
\hline \multirow[t]{3}{*}{150} & 5 & $10.33 \pm 0.2^{\mathrm{a}}$ & $9.26 \pm 0.1^{\mathrm{a}}$ & $8.21 \pm 0.2^{\mathrm{a}}$ & $7.12 \pm 0.0^{\mathrm{a}}$ & $7.02 \pm 0.3^{\mathrm{a}}$ & $67.96 \pm 1.0^{\mathrm{a}}$ \\
\hline & 10 & $10.27 \pm 0.1^{\mathrm{a}}$ & $9.19 \pm 0.2^{\mathrm{a}}$ & $8.13 \pm 0.2^{\mathrm{a}}$ & $7.06 \pm 0.2^{\mathrm{a}}$ & $6.99 \pm 0.2^{\mathrm{a}}$ & $68.06 \pm 0.8^{\mathrm{a}}$ \\
\hline & 15 & $10.23 \pm 0.1^{\mathrm{a}}$ & $9.21 \pm 0.1^{\mathrm{a}}$ & $8.18 \pm 0.1^{\mathrm{a}}$ & $7.13 \pm 0.1^{\mathrm{a}}$ & $7.06 \pm 0.1^{\mathrm{a}}$ & $69.01 \pm 0.3^{\mathrm{a}}$ \\
\hline \multirow[t]{3}{*}{160} & 5 & $10.28 \pm 0.1^{\mathrm{a}}$ & $9.21 \pm 0.1^{\mathrm{a}}$ & $8.14 \pm 0.0^{\mathrm{a}}$ & $7.00 \pm 0.2^{\mathrm{a}}$ & $6.98 \pm 0.2^{\mathrm{a}}$ & $67.90 \pm 0.9^{\mathrm{a}}$ \\
\hline & 10 & $10.22 \pm 0.4^{\mathrm{a}}$ & $9.15 \pm 0.1^{\mathrm{a}}$ & $8.10 \pm 0.1^{\mathrm{a}}$ & $7.03 \pm 0.2^{\mathrm{a}}$ & $6.98 \pm 0.1^{\mathrm{a}}$ & $68.29 \pm 0.3^{\mathrm{a}}$ \\
\hline & 15 & $10.20 \pm 0.4^{\mathrm{a}}$ & $9.16 \pm 0.1^{\mathrm{a}}$ & $8.11 \pm 0.0^{\mathrm{a}}$ & $7.06 \pm 0.1^{\mathrm{a}}$ & $7.00 \pm 0.3^{\mathrm{a}}$ & $68.63 \pm 0.8^{\mathrm{a}}$ \\
\hline \multirow[t]{3}{*}{170} & 5 & $10.24 \pm 0.1^{\mathrm{a}}$ & $9.20 \pm 0.2^{\mathrm{a}}$ & $8.14 \pm 0.2^{\mathrm{a}}$ & $6.98 \pm 0.1^{\mathrm{b}}$ & $6.47 \pm 0.1^{\mathrm{b}}$ & $63.18 \pm 0.3^{b}$ \\
\hline & 10 & $10.22 \pm 0.4^{\mathrm{a}}$ & $9.20 \pm 0.1^{\mathrm{a}}$ & $8.24 \pm 0.1^{\mathrm{a}}$ & $6.91 \pm 0.0^{\mathrm{b}}$ & $6.50 \pm 0.1^{\mathrm{b}}$ & $63.60 \pm 1.1^{b}$ \\
\hline & 15 & $10.26 \pm 0.1^{\mathrm{a}}$ & $9.22 \pm 0.2^{\mathrm{a}}$ & $8.13 \pm 0.1^{\mathrm{a}}$ & $6.98 \pm 0.0^{\mathrm{b}}$ & $6.59 \pm 0.1^{\mathrm{b}}$ & $64.23 \pm 1.0^{\mathrm{b}}$ \\
\hline
\end{tabular}

Note: Data is presented as mean \pm standard deviation $(\mathrm{n}=3)$

Different superscript in each column represents a significant difference between mean values at $95 \%(\mathrm{p} \leq 0.05)$

Physical characteristic and survival of microencapsulated $L$. casei TISTR 390 containing inulin powder

To investigate the effect of the prebiotic on the physical properties and the survival rate of the microencapsulated cells, inulin was added to the medium. Maltodextrin is the most commonly used as a carrier for powder production. Currently, the application of mixtures consisting of different carriers has been done not only to provide an advantage for the technical points such as beneficial for drying process or final physical properties of the powders obtained, but also had additional benefits for human health. Inulin is one of the spray-dried carriers which has the function in term of technical support for the drying process and benefit as functional food aspect [17]. The combination of maltodextrin and inulin as a carrier for drying probiotics strain, L. casei TISTR 390, is promising as a synbiotic product. To evaluate the influence of the combination of maltodextrin and inulin on the physical properties and stability in simulated gastrointestinal conditions as well as during storage, the experiments were conducted at a constant inlet temperature $\left(160{ }^{\circ} \mathrm{C}\right)$. Various levels of inulin $(5,10$ and $15 \%)$ were added and substituted for the maltodextrin content, taking into account the production cost. Data in Table 4 showed that the moisture content and water activity of the microencapsulated L. casei TISTR 390 containing inulin powder were $1.5-2.2 \%$ and $0.28-0.31$, respectively. The microcapsule obtained from T1 had physical properties including moisture content, $\mathrm{a}_{\mathrm{w}}$, bulk density, and solubility which had differed from T2 and T3 significantly $(\mathrm{p}<0.05)$.

Table 4 Physical properties of microencapsulated L. casei TISTR 390 containing inulin at different spray drying conditions.

\begin{tabular}{ccccccc}
\hline $\begin{array}{c}\text { Maltodextrin } \\
(\%)\end{array}$ & $\begin{array}{c}\text { Inulin } \\
(\%)\end{array}$ & $\begin{array}{c}\text { Moisture } \\
(\%)\end{array}$ & $\mathbf{a}_{\mathbf{w}}$ & $\begin{array}{c}\text { Bulk density } \\
\mathbf{( g / m L )}\end{array}$ & $\begin{array}{c}\text { Solubility } \\
(\mathbf{\%})\end{array}$ & $\begin{array}{c}\text { Survival } \\
(\%)\end{array}$ \\
\hline 15 & 5 & $2.2 \pm 0.05^{\mathrm{a}}$ & $0.31 \pm 0.01^{\mathrm{a}}$ & $0.66 \pm 0.01^{\mathrm{a}}$ & $79.16 \pm 0.02^{\mathrm{a}}$ & $90.04 \pm 0.5^{\mathrm{a}}$ \\
10 & 10 & $1.5 \pm 0.01^{\mathrm{b}}$ & $0.28 \pm 0.02^{\mathrm{b}}$ & $0.71 \pm 0.04^{\mathrm{b}}$ & $84.71 \pm 0.01^{\mathrm{b}}$ & $90.76 \pm 0.5^{\mathrm{a}}$ \\
5 & 15 & $1.5 \pm 0.00^{\mathrm{b}}$ & $0.28 \pm 0.00^{\mathrm{b}}$ & $0.72 \pm 0.03^{\mathrm{b}}$ & $84.70 \pm 0.01^{\mathrm{b}}$ & $90.00 \pm 0.8^{\mathrm{a}}$
\end{tabular}

Note: Data is presented as mean \pm standard deviation $(n=3)$

Different superscript in each column represents a significant difference between mean values at $95 \%(\mathrm{p} \leq 0.05)$. 
It could be suggested that the moisture content and water activity obtained from $\mathrm{T} 1$ were higher than others, because the highest level of maltodextrin has a small and ramified structure that can make water adsorption easier [14], and the addition of inulin $10-15 \%$ can improve the physical properties as well as the hygroscopicity of the powder similarly observed by Kingwatee et al. [23]. Fritzen-Freire et al. [5] reported that inulin had a positive effect on the protection of bifidobacteria during the encapsulation process, probably because it acted as a thermoprotector for the cells undergoing the drying process. Figure 2 showed SEM micrographs of encapsulated L. casei TISTR 390 containing inulin. Figures 2(B) and 2(C) respectively showed a smooth surface in spherical shape, whereas, Figure 2(A) showed an uneven shrinkage shape. Laokuldilok and Kanha [30] explained that the particles with smoother surfaces could protect their cores from oxidation during storage better than particles containing more surface cracks and indentations. The ideal structure in the microencapsulation process is a uniform and smooth surface, with a slightly spherical shape with minimum cracks and collapses on its wall [27]. In addition, Figure 2 clearly showed that the microencapsulated powder obtained had a size difference and Figure 2(C) (T3: $5 \%$ MD $+15 \%$ inulin (w/v)) showed the biggest size. As mentioned earlier, the larger particles contained more entrapped air which resulted in lowering the bulk density effect to poor storage. In this case, T2; maltodextrin $10 \%+10 \%$ inulin as wall material gave the best results.

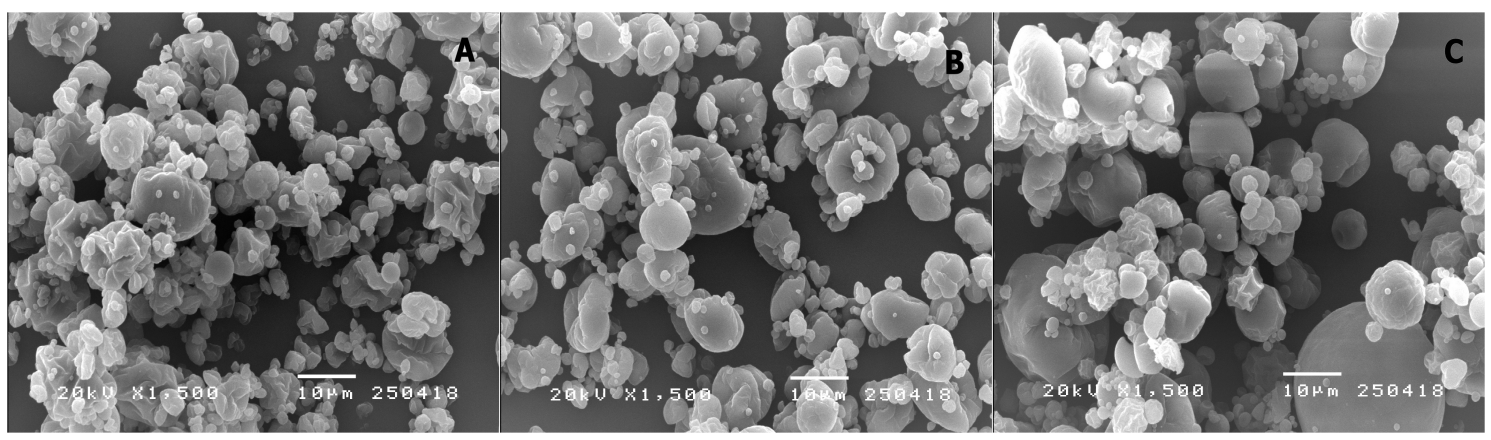

Figure 2 Scanning electron micrographs $1500 \times$ magnification of microencapsulated $L$. casei TISTR 390 at $160{ }^{\circ} \mathrm{C}$ inlet temperature with $\mathrm{A}=\mathrm{T} 1: 15 \% \mathrm{MD}+5 \%$ inulin $(\mathrm{w} / \mathrm{v}), \mathrm{B}=\mathrm{T} 2: 10 \% \mathrm{MD}+10 \%$ inulin $(\mathrm{w} / \mathrm{v})$ and $\mathrm{C}=\mathrm{T} 35 \% \mathrm{MD}+15 \%$ inulin $(\mathrm{w} / \mathrm{v})$.

\section{Survival of microencapsulated L. casei TISTR 390 containing inulin powder in gastrointestinal conditions \\ The maintenance of microorganism viability throughout the gastrointestinal tract is one of the major} challenges to the food industry. The acidic environment and enzymes from the stomach, as well as bile salts secreted into the duodenum, are the main obstacles to the survival of ingested bacteria. In this study, the survival rate of microencapsulated L. casei TISTR 390 containing inulin powder in simulated gastric juice and bile salt is shown in Tables 5 and 6. The results showed that L. casei TISTR 390 coencapsulated with inulin had viability around 5.77 - $6.92 \log \mathrm{CFU} / \mathrm{g}$ after incubating in simulated gastrointestinal conditions for $120 \mathrm{~min}$ and showed higher cell viability than spray drying without inulin. This present work revealed that inulin had promoted good encapsulation efficiency, making it a potential protective agent the same as the results obtained by Nunes et al. [36]. Peredo et al. [37] also reported that the probiotic bacteria co-encapsulated with prebiotic showed higher viability after intestinal simulation than capsules without prebiotics. They explained that because inulin is a soluble fiber that reaches the large intestine without modification and is available to be metabolized by microorganism as bifidobacteria and lactobacillus. The combination of probiotics and prebiotics is known as a synbiotic and is used in food products to take advantage of the synergic effect. Similar results reported by Kingwatee et al. [23], L. casei 01 in lychee juice powder coated with $15 \%$ maltodextrin plus $5 \%$ inulin led to cell survivability up to $60 \mathrm{~min}$ in gastric juice and up to $120 \mathrm{~min}$ in $2 \%$ bile salt solution. Santos et al. [38] showed that L. acidophilus La-5 encapsulated with inulin had a high survival in the in-vitro simulated gastrointestinal conditions and suggested inulin as a high potential coating agent for the microencapsulation probiotic stains. 
Table 5 Viability of microencapsulated L. casei TISTR 390 containing inulin in simulated gastric juice.

\begin{tabular}{|c|c|c|c|c|c|c|c|}
\hline \multirow{2}{*}{$\begin{array}{c}\text { Maltodextrin } \\
(\%)\end{array}$} & \multirow{2}{*}{$\begin{array}{c}\text { Inulin } \\
(\%)\end{array}$} & \multicolumn{5}{|c|}{ Viability in simulated gastric juice (Log CFU/g) } & \multirow{2}{*}{$\begin{array}{c}\text { Survival } \\
(\%)\end{array}$} \\
\hline & & $0 \min$ & $30 \mathrm{~min}$ & $60 \mathrm{~min}$ & $90 \mathrm{~min}$ & $120 \mathrm{~min}$ & \\
\hline 15 & 5 & $9.05 \pm 0.2^{\mathrm{a}}$ & $8.01 \pm 0.2^{\mathrm{a}}$ & $7.09 \pm 0.1^{\mathrm{a}}$ & $6.92 \pm 0.1^{\mathrm{a}}$ & $5.77 \pm 0.1^{\mathrm{a}}$ & $63.75 \pm 0.6^{\mathrm{a}}$ \\
\hline 10 & 10 & $9.19 \pm 0.2^{\mathrm{a}}$ & $8.04 \pm 0.2^{\mathrm{a}}$ & $7.19 \pm 0.1^{\mathrm{a}}$ & $6.98 \pm 0.1^{\mathrm{a}}$ & $5.88 \pm 0.2^{\mathrm{a}}$ & $63.98 \pm 0.3^{\mathrm{a}}$ \\
\hline 5 & 15 & $9.12 \pm 0.1^{\mathrm{a}}$ & $8.09 \pm 0.1^{\mathrm{a}}$ & $7.06 \pm 0.2^{\mathrm{a}}$ & $6.94 \pm 0.2^{\mathrm{a}}$ & $5.83 \pm 0.2^{\mathrm{a}}$ & $63.92 \pm 0.2^{\mathrm{a}}$ \\
\hline
\end{tabular}

Note: Data is presented as mean \pm standard deviation $(\mathrm{n}=3)$

Different superscript in each column represents a significant difference between mean values at $95 \%(\mathrm{p} \leq 0.05)$.

Table 6 Viability of microencapsulated L. casei TISTR 390 containing inulin in simulated bile salt.

\begin{tabular}{cccccccc}
\hline $\begin{array}{c}\text { Maltodextrin } \\
(\%)\end{array}$ & Inulin & \multicolumn{5}{c}{ Viability in simulated bile salt (Log CFU/g) } & Survival \\
\cline { 3 - 6 } & $(\%)$ & $0 \min$ & $30 \mathrm{~min}$ & $60 \mathrm{~min}$ & $90 \mathrm{~min}$ & $120 \mathrm{~min}$ & $(\%)$ \\
\hline 15 & 5 & $9.04 \pm 0.1^{\mathrm{a}}$ & $8.99 \pm 0.2^{\mathrm{a}}$ & $7.97 \pm 0.1^{\mathrm{a}}$ & $6.86 \pm 0.1^{\mathrm{a}}$ & $6.85 \pm 0.2^{\mathrm{a}}$ & $75.77 \pm 0.3^{\mathrm{a}}$ \\
10 & 10 & $9.07 \pm 0.2^{\mathrm{a}}$ & $8.70 \pm 0.2^{\mathrm{a}}$ & $7.95 \pm 0.1^{\mathrm{a}}$ & $6.96 \pm 0.1^{\mathrm{a}}$ & $6.92 \pm 0.2^{\mathrm{a}}$ & $76.30 \pm 0.6^{\mathrm{a}}$ \\
5 & 15 & $9.03 \pm 0.1^{\mathrm{a}}$ & $8.98 \pm 0.1^{\mathrm{a}}$ & $7.91 \pm 0.2^{\mathrm{a}}$ & $6.85 \pm 0.2^{\mathrm{a}}$ & $6.87 \pm 0.1^{\mathrm{a}}$ & $76.08 \pm 0.7^{\mathrm{a}}$ \\
\hline
\end{tabular}

Note: Data is presented as mean \pm standard deviation $(\mathrm{n}=3)$

Different superscript in each column represents a significant difference between mean values at $95 \%(\mathrm{p} \leq 0.05)$.

\section{Storage stability of microencapsulated powder}

To exert their beneficial health effects, probiotics must be viable when delivered. In products where a health claim is announced, it is necessary to know the number of viable microorganisms found at the end of the shelf-life of the products rather than at their beginning [1]. Although spray drying is a popular preservation technique widely used in the food industry, the low viability of probiotic cultures has been reported.

Figure 3 showed the storage stability result of the microencapsulated powder when kept at room temperature $\left(32-35{ }^{\circ} \mathrm{C}\right)$ for 6 weeks. Moisture content, water activity, and survivability were investigated compared to the initial state. It was found that moisture content and $\mathrm{a}_{\mathrm{w}}$ were increased between $2.8-3.5 \%$ and $0.31-0.36$, respectively. These may be due to exposure to the humidity of the environmental conditions during storage. Microencapsulated powder coated with $15 \%$ maltodextrin (T0 and T1) showed higher moisture content than T2 and T3 significantly $(p>0.05)$. Similar results have been reported that Bifidobacterium spp. encapsulated with $50 \%$ maltodextrin plus $50 \%$ inulin had the lowest hygroscopicity value while the powders produced only with maltodextrin showed the highest water adsorption results in higher water activity [14]. However, the result obtained in this study showed that the combination of maltodextrin and inulin did not enhance viability during storage. The cell survival of co-encapsulated powder after storage for 6 weeks was not significantly different $(p>0.05)$.

Most developed spray-dried probiotic powders can maintain viability at $4{ }^{\circ} \mathrm{C}[4,19,34]$, but the real challenge is to ensure a reasonable shelf life for these products at room temperature. Hence, in this study, the survival of microencapsulated $L$. casei TISTR 390 was investigated. It was observed that the survivability rate of co-encapsulated capsules was decreased to $70 \%$, but cell viability remains at $6 \log$ $\mathrm{CFU} / \mathrm{g}$ after 6 weeks in ambient temperature $\left(32-35^{\circ} \mathrm{C}\right)$ when packed in an aluminum-laminated bag. There were approximately 4 log cycle losses in cell numbers of encapsulated L. casei TISTR 390 without inulin, whereas, the co-encapsulated cells with inulin in all combinations showed only 3 log cycle losses in cell numbers. The results revealed that co-encapsulation of probiotics with prebiotics constitutes an alternative for maintaining their viability during storage at room temperature for more than 30 days, similar results have been reported by Nunes et al. [35] and Peredo et.al. [36]. Upadhyay and Dass J [39] reported that the survival of $L$. plantarum in guava juice powder using $10 \%$ maltodextrin and $10 \%$ inulin had a survival rate of $80 \%$ for 45 days at $4{ }^{\circ} \mathrm{C}$ and $85 \%$ for 15 days at room temperature $\left(25^{\circ} \mathrm{C}\right)$. 


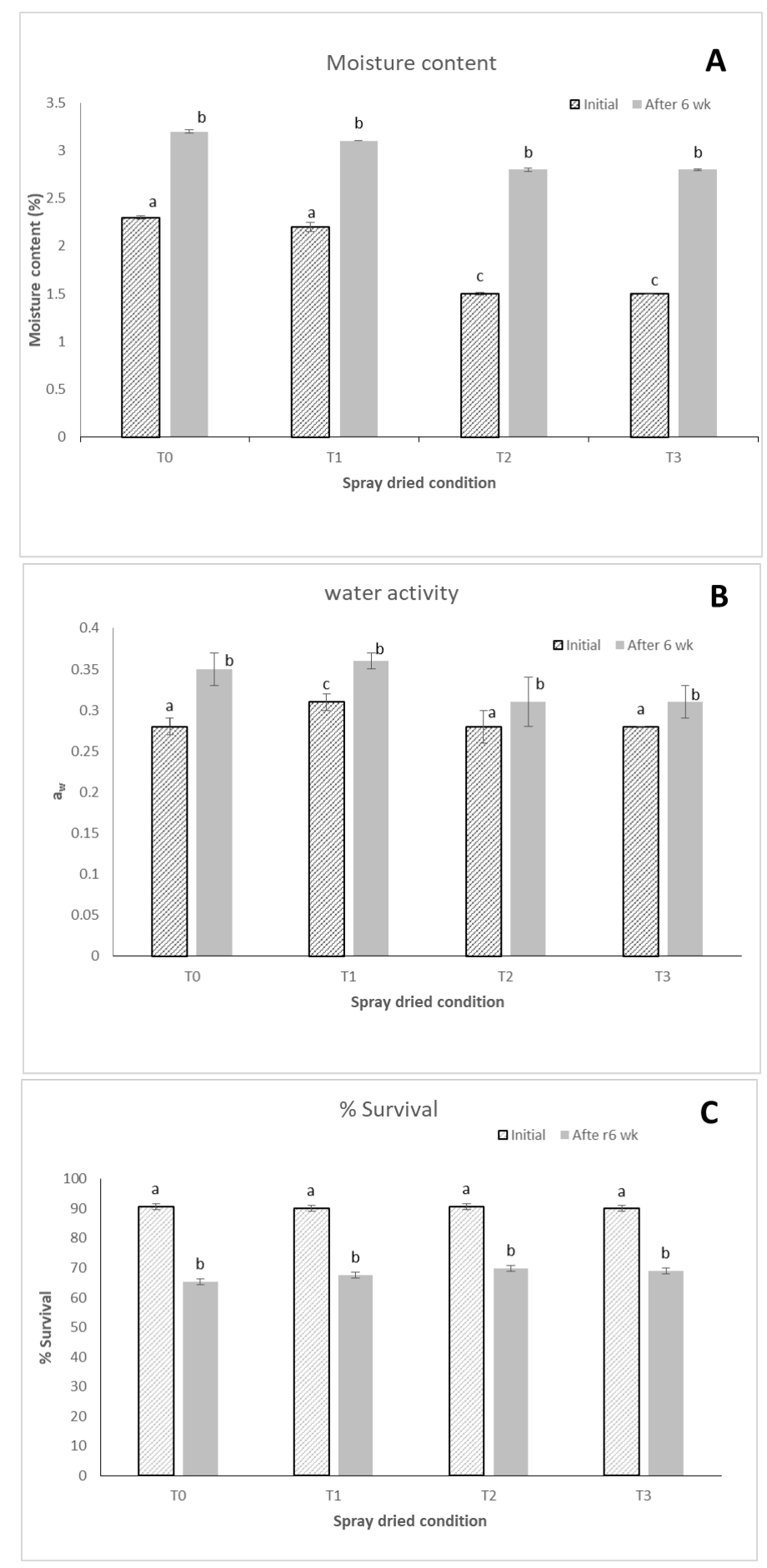

Figure 3 Moisture content (A), water activity (B) and survivability (C) of microencapsulated L. casei TISTR 390 containing inulin before and after storage for 6 weeks. T0 $=15 \% \mathrm{MD}, \mathrm{T} 1=15 \% \mathrm{MD}+5 \%$ inulin, $\mathrm{T} 2=10 \% \mathrm{MD}+10 \%$ inulin and $\mathrm{T} 3=5 \% \mathrm{MD}+15 \%$. 


\section{Conclusions}

In conclusion, the application of microencapsulation of probiotics bacteria L. casei TISTR 390 by spray drying technique acted as a protective shield against the severe conditions of the gastrointestinal tract since the viable cell count showed above the minimum requirement for conferring a probiotic effect. The optimum inlet temperature was $160{ }^{\circ} \mathrm{C}$ because it produced a powder with a high survival rate after spray-dried and also after incubated in simulated gastrointestinal condition. In addition, $10 \%$ maltodextrin $+10 \%$ inulin had been shown as an appropriate carrier to encapsulate the viable cells from being damaged by heat, gastrointestinal fluids, and storage conditions. Hence, microencapsulation of $L$. casei TISTR 390 with maltodextrin and inulin was found to be most effective in retaining the viability of bacteria after drying; in simulated gastrointestinal conditions, and during storage at room temperature (32 $-35^{\circ} \mathrm{C}$ ). Therefore, the production of synbiotic microcapsules with the combination of maltodextrin and inulin wall matrix by spray drying method has potential applications in the functional food industry. The beneficial impact of this synbiotic powder on improving human health status should be further studied.

\section{Acknowledgments}

The financial support for this work provided by The National Research Council of Thailand (NRCT) is gratefully acknowledged. The author would like to thank The Thailand Institute of Scientific and Technological Research and Faculty of Agricultural Technology, Valaya Alongkorn Rajabhat University, Pathumtani Thailand for the scientific support and the use of their facilities.

\section{References}

[1] FAO/WHO. Evaluation of health and nutritional properties of powder milk with live lactic acid bacteria. Report from FAO/WHO Export Consultation 1 - 4 October, Cordoba, Argentina. 2001, Available at: http://www.fao.org/es/ESN/probiot/probio.htm, accessed January 2018.

[2] DY Ying, J Sun, L Sanguansri, R Weerakkody and MA Augustin. Enhanced survival of spray-dried microencapsulated Lactobacillus rhamnosus GG in the presence of glucose. J. Food Eng. 2012; 109, 597-602.

[3] S Arslan, M Erbas, I Tontul and A Topus. Microencapsulation of probiotic Saccharomyces cerevisiae var. boulardii with different wall materials by spray drying. LWT-Food Sci. Technol. 2015; 63, 685-90.

[4] D Arepally, RS Reddy and TK Goswami. Studies on survivability, storage stability of encapsulated spray dried probiotic powder. Curr. Res. Food Sci. 2020; 3, 235-42.

[5] CB Fritzen-Freire, ES Prudencio, RDMC Amboni, SS Pinto, AN Nagrao-Murakami and FS Murakami. Microencapsulation of bifidobacteria by spray drying in the presence of prebiotics. Food Res. Int. 2012; 45, 306-12.

[6] O Gul and M Dervisoglu. Optimization of spray drying conditions for microencapsulation of Lactobacillus casei Shirota using response surface methodology. Eur. Food Sci. Eng. 2020; 1, 1-8.

[7] GM Maciel, KS Chaves, CRF Grosso and ML Gigante. Microencapsulation of Lactobacillus acidophilus La-5 by spray-drying using sweet whey and skim milk as encapsulating materials. $J$. Dairy Sci. 2014; 97, 1991-8.

[8] W Lapsiri, B Bhandari and P Wanchaitananwong. Viability of Lactobacillus plantarum TISTR 2075 in different protectants during spray drying and storage. Dry. Technol. 2012; 30, 1407-12.

[9] S Behboudi-Jobbehdar, C Soukoulis, L Yonekura and I Fisk. Optimization of spray-drying process conditions for the production of maximally viable microencapsulated L.acidophilus NCIMB 701748. Dry. Technol. 2013; 31, 1274-83.

[10] L Yonekura, H Sun, C Soukoulis and I Fisk. Microencapsulation of Lactobacillus acidophilus NCIMB 701748 in matrices containing soluble fibre in spray drying: Technological characterization, storage stability and survival after in vitro digestion. J. Funct. Food. 2014; 6, $205-$ 14.

[11] Z Zhu, C Luan, H Zhang, L Zhang and Y Hao. Effect of spray drying on Lactobacillus plantarum BM-1 viability, resistance to simulated gastrointestinal digestion and storage stability. Dry. Technol. 2016; 34, 177-84.

[12] S Sathyabama, MR Kuma, PB Devi, R Vijayabharathi and VB Priyadharisini. Co-encapsulation of probiotics with prebiotics on alginate matrix and its effect on viability in simulated gastric environment. LWT-Food Sci. Technol. 2014; 57, 419-25. 
[13] MAR Mazumder and TV Ranganathan. Encapsulation of isoflavone with milk, maltodextrin and gum acacia improves its stability. Curr. Res. Food Sci. 2020; 2, 77-83.

[14] DRSF Paim, SDO Costa, EHM Walter and RV Tonon. Microencapsulation of probiotic jussara (Euterpe edulis M.) juice by spray drying. LWT-Food Sci. Technol. 2016; 74, 21-5.

[15] K Sarabandi, SH Peighambardoust, AS Mahoonak and SP Samaei. Effect of carrier types and compositions on the production yield microstructure and physical characteristics of spray dried sour cherry juice concentrate. J. Food Meas. Charact. 2017; 11, 1602-12.

[16] N Fu and XD Chen. Towards a maximal cell survival in convective thermal drying processes. Food Res. Int. 2011; 44, 1127-49.

[17] K Slizewska and A Chlebica-Wojcik. The in vitro analysis of prebiotics to be used as a component of a symbiotic preparation. Nutrients 2020; 12, 1272.

[18] J Moludi, H Khedmatgozar, SM Nachvak, H Abdollahzad, M Moradinazar and A Tabaei. The effects of co-administration of probiotics and prebiotics on chronic inflammation, and depression symptoms in patients with coronary artery diseases: A randomized clinical trial. Nutr. Neurosci. 2021. http://doi.org/10.1080/1028415X.2021.1889451.

[19] D Dimitrellou, P Kandylis, S Levic, S Dimitrijevic-Brankovic, T Petrovic, V Nedovic and Y Kourkoutas. Survival of spray dried microencapsulated Lactobacillus casei ATTC 393 in simulated gastrointestinal conditions and fermented milk. LWT-Food Sci. Technol. 2016; 71, 169-74.

[20] S Nilsang. Effect of spray drying temperature on quality of instant herbal drinks. FAB J. 2018; 6, 55-68.

[21] Association of Official Analytical Chemists (AOAC). Official methods of analysis of AOAC international, $17^{\text {th }}$ ed. AOAC International, Gaithersburg, MD. 2000, p. xx.

[22] D Kunapornsujarit and P Intipunya. Effect of spray drying temperature on quality of longan beverage powder. FAB J. 2013; 1, 81-9.

[23] N Kingwatee, A Apichartsrangkoon, $\mathrm{P}$ Chaikham, $\mathrm{S}$ Worametrachanon, $\mathrm{J}$ Techarung and $\mathrm{T}$ Pankasemasuk. Spray drying Lactobacillus casei 01 in lychee juice varied carrier materials. $L W T$ Food Sci. Technol. 2015; 62, 847-53.

[24] K Khwanpruk, C Akkaraphenphan, P Wattananukit, W Kaewket and S Chusai. Effect of drying air condition and feed composition on the properties of orange juices spray dried powder. MATEC Web Conf. 2018; 192, 03013.

[25] D Poddar, S Das, G Jones, J Palmer, GB Jameson, RG Haverkamp and H Singh. Stability of probiotic Lactobacillus paracasei during storage as affected by the drying method. Int. Dairy J. 2014; 39, 1-7.

[26] ACLD Medeiros, M Thomazini, A Urbano, RTP Correia and CS Favaro-Trindade. Structural characterization and cell viability of a spray dried probiotic yoghurt produced with goats' milk and Bifidobacterium animalis subsp. lactis (BI-07). Int. Dairy J. 2014; 39, 71-7.

[27] GC Koc and SN Dirim. Spray dried spinach juice: Powder properties. J. Food Meas. Charact. 2018; 12, 1654-68.

[28] D Kalita, S Saika, G Gautam, R Mukhopadhyay and CL Mahanta. Characteristics of synbiotic spray dried powder of litchi juice with Lactobacillus plantarum and different carrier materials. LWT-Food Sci. Technol. 2018; 87, 351-60.

[29] SC Lourenco, M Moldao-Martins and VD Alves. Microencapsulation of pineapple peel extract by spray drying using maltodextrin, inulin, and Arabic gum as wall matrices. Foods 2020; 9, 718.

[30] $\mathrm{T}$ Laokuldilok and $\mathrm{N}$ Kanha. Effects of processing conditions on powder properties of black glutinous rice (Oryza sativa L.) bran anthocyanins produced by spray drying and freeze drying. LWT-Food Sci. Technol. 2015; 64, 405-11.

[31] K A-sun, B Thumthanaruk, S Lekhavat and R Jumnongpon. Effect of spray drying condition on physical characteristics of coconut sugar powder. Int. Food Res. J. 2016; 23, 1315-9.

[32] P Mishra, S Mishra and CL Mahanta. Effect of maltodextrin concentration and inlet temperature during spray drying on physicochemical and antioxidant properties of amla (Emblica officinalis) juice powder. Food Bioprod. Process. 2014; 92, 252-8.

[33] MJ Navarro-Flores, LMC Ventura-Canseco, R Meza-Gordillo, TDR Ayora-Talavera and M AbudArchila. Spray drying encapsulation of a native plant extract rich in phenolic compounds with combinations of maltodextrin and non-conventional wall materials. J. Food Sci. Technol. 2020; 57, 4111-22.

[34] A Ghandi, IB Powell, XD Chen and B Adhikari. The effect of dryer inlet and outlet air temperatures and protectant solids on the survival of Lactococcus lactis during spray drying. Dry. Technol. 2012; 30, 1649-57. 
[35] K Farhmandi, S Rajab, F Tabandeh, MK Shahraky, A Maghsoudi and M Ashengroph. Efficient spray-drying of Lactobacillus rhamnosus PTTC 1637 using total CFU yield as the decision factor. Food Biosci. 2021; 40, 100816.

[36] GL Nunes, MDA Etchepare, AJ Cichoski, LQ Zepka, EJ Lopes, JS Barin, EMDM Flores, CDBD Silva and CRD Menezes. Inulin, hi-maize and trehalose as thermal protectants for increasing viability of Lactobacillus acidophilus encapsulated by spray drying. LWT-Food Sci. Technol. 2018; 89, 128-33.

[37] AG Peredo, CI Beristain, LA Pascual, E Azuara and M Jimenez. The effect of prebiotics on the viability of encapsulated probiotic bacteria. LWT-Food Sci. Technol. 2016; 73, 191-6.

[38] DXD Santos, AA Casazza, B Aliakbarian, R Bedani, SMI Saad and P Perego. Improved probiotic survival to in vitro gastrointestinal stress in a mousse containing Lactobacillus acidophilus La-5 microencapsulated with inulin by spray drying. LWT-Food Sci. Technol. 2019; 99, 404-10.

[39] R Upadhyay and FP Dass J. Physicochemical analysis, microbial survivability, and shelf life study of spray-dried synbiotic guava juice powder. J. Food Process Preserv. 2021; 45, e15103. 